\title{
A Multi-Disciplinary Review of Current Sea-Level Rise Research in Florida ${ }^{1}$
}

\author{
Anna Cathey Linhoss, Lisa Gardner Chambers, Kevin Wozniak, and Tom Ankersen²
}

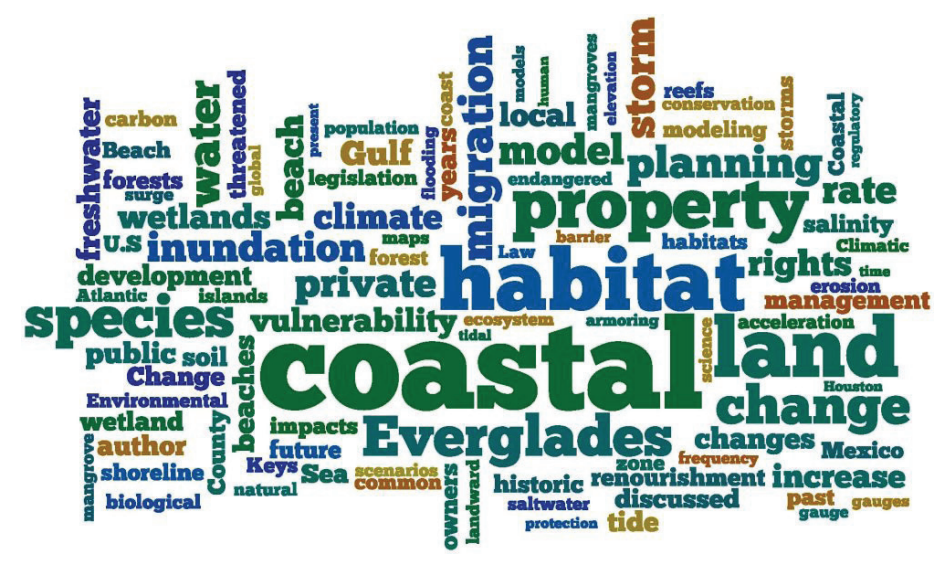

\section{Abstract}

Sea-level rise is an issue of paramount importance for the state of Florida due to its lengthy coastline, low relief, high coastal population density, ecologically and economically vital beaches, estuaries, and wetlands, and porous limestone geology. The rate of sea-level rise in Florida generally follows the global average ( $\sim 3 \mathrm{~mm}$ per year) and is slowly gaining public attention as a significant threat to the natural and socioeconomic future of the state. This multidisciplinary review provides an annotated bibliographic summary of current peer-reviewed literature regarding sea-level rise in Florida. The authors also offer an analysis of research topic areas defined for the purpose of identifying knowledge gaps in the peer-reviewed literature. Fifty-five articles with direct relevance to Florida were divided into three broad categories (physical, biological, and social sciences), assigned place and subject keywords, and summarized. The keyword analysis revealed an emphasis on research addressing habitat migration, modeling, wetlands, inundation (flooding), land-use planning, legislation, and private property rights. The Gulf of Mexico, Everglades, Big Bend and Florida Keys are the most common geographic locations discussed in the literature. Topics the authors perceive as underrepresented in the current literature are presented and discussed, including saltwater intrusion to groundwater, the economic consequences of sea-level rise, threats to intangible coastal ecosystem services (nutrient cycling, shoreline protection), and the sustainability of certain habitat types (seagrass beds, coral reefs). With a continually expanding body of research, this paper serves as a "one-stop shop" for researchers, planners, and policy makers to quickly review the current state of the science on sea-level rise in Florida.

\section{Introduction}

According to the Intergovernmental Panel on Climate Change, Florida was the last state to emerge from the ocean following the last interglacial period and has experienced fluctuations in sea level of $120 \mathrm{~m}$ in the past 21,000 years (IPCC 2007).

Sea-level rise and climate change are global phenomena. However, spatial and temporal changes in sea level vary on

1. This document is TP193, one of a series of the Florida Sea Grant College Program, Institute of Food and Agricultural Sciences, University of Florida. Original publication date February 2013. Visit the EDIS website at http://edis.ifas.ufl.edu.

2. Anna Cathey Linhoss, assistant professor, Department of Agricultural and Biological Engineering, Mississippi State University; Lisa Gardner Chambers, PhD student, Department of Soil and Water Science; Kevin Wozniak, JD student, University of Florida Levin College of Law; and Tom Ankersen, professor, University of Florida Levin College of Law; University of Florida Institute of Food and Agricultural Sciences, Gainesville, FL 32611. 
local and regional scales due to differences in ocean density, circulation patterns, climatic events, coastal geomorphology, and topography. Issues of scale are important when considering sea-level rise. Many of the considerations in the broader sea-level rise literature, such as human-caused (anthropogenic) contributions to climate change and the role of glacial melt in future predictions, are best addressed at a global scale. Other issues of more regional and local significance, including land loss, habitat migration, vulnerability, and land-use planning, are best addressed at the local level. This bibliography maintains a regional focus on Florida-specific sea-level rise literature.

In the 2,000 years before 1850, global sea level was fairly constant. Sea level began to rise at a rate of $\sim 2 \mathrm{~mm}$ per year from 1850-1950, and increased to a rate of $\sim 3 \mathrm{~mm}$ per year after 1993 (IPCC 2007). Approximately half of the rise is attributed to the thermal expansion of the ocean and half to the transfer of land water and ice to the oceans. In general, relative sea-level rise in Florida has mimicked the rate of global sea-level rise, with some local variability even within the state.

Understanding sea-level rise in Florida requires both a historical perspective and the ability to use predictive sciences to forecast future conditions using numeric and physical models. The historic record is rooted in geologic sciences but also includes archaeology, anthropology, and the use of biological indicators of past circumstances. Relying on the historic record, predictions of future sea-level impacts and inundation maps can be constructed using scenarios, probability, and physical elevation data. Predictive models are only as accurate as the historic data used to construct them. Therefore, as our understanding of the past increases, and as the present becomes the past, our predictions become increasingly accurate. Sea-level rise science is continually evolving and has increasingly caught the attention of the social sciences (economics, law, and planning) interested in how sea-level change will impact the human condition.

This summary of research includes published peer-reviewed literature related to sea-level rise in Florida through January 2012. We have excluded the large body of gray literature available from government agencies, universities, and conservation organizations. Instead, we have focused exclusively on peer-reviewed literature, or publications in journals accepted by their discipline on the basis of scholarship. This literature was compiled by an interdisciplinary team of scientists and attorneys using a number of search engines, databases, and internal references, including but not limited to, Google Scholar, Web of Knowledge, Westlaw, and author and key word searches. Fifty-four publications are summarized and grouped into three broad categories: physical, biological, and social sciences. We have made every effort to briefly, objectively, and accurately summarize each publication. We do not pretend to grasp the disciplinary subtleties and complexities that all subject matter embraced. Any errors or omissions are the responsibility of the authors of this bibliography.

A second goal of this research is to provide a general analysis of the types of topics covered in the current sea-level rise literature and a discussion of topics and geographic areas of study that we feel are under-represented in the literature. We did this through a meta-analysis of keywords common to sea-level rise literature. The results of the meta-analysis are presented in the conclusion of this document. Gaps in this body of literature, as perceived by the authors, are also discussed.

\section{Physical Science}

Adams, P. N.; Opdyke, N. D.; and Jaeger, J. M., 2010. Isostatic uplift driven by karstification and sea-level oscillation: Modeling landscape evolution in north Florida. Geology, 38(6), 531-534.

\section{Keywords: historic sea-level rise, karst, modeling}

The limestone and dolostone that forms Florida's platform is dissolved by freshwater at and below ground level. This process, called karstification, decreases the density and weight of the rock. As a result, isostatic uplift occurs, a process in which the lithosphere rises to reach gravitational equilibrium. This paper presents a numerical model that accounts for changes in sea level, karstification, precipitation, and isostatic uplift in order to age geologic features. The model also shows that the rate of uplift due to karstification is approximately $1 / 20 \mathrm{~mm}$ per year, indicating that the Florida platform is not completely stable relative to sea level.

Chu-Agor, M.L.; Muñoz-Carpena, R.; Kiker, G.A.; Emanuelsson, A.; and Linkov, I., 2011. Exploring sea level rise vulnerability of coastal habitats through global sensitivity and uncertainty analysis. Environmental Modelling \& Software, 26(5), 593-604.

Keywords: barrier islands, habitat migration, inundation, modeling, Panhandle, threatened and endangered species, wetlands, Gulf of Mexico

This work uses the Sea Level Affecting Marshes Model (SLAMM) to simulate changes in inundation and wetland 
migration associated with sea-level rise at Eglin Air Force Base's barrier islands in the Florida Panhandle. Sensitivity analysis was used to show that the most important variables driving model behavior are the vertical error of land elevation maps, historic trend of sea-level change, accretion, and sedimentation rates. The results also indicate that low-elevation habitats, such as salt marshes and tidal flats, exhibit a mix of gains and losses in overall area due to the ability of these habitats to migrate landward in response to sea level. However, habitats at higher elevations generally show a loss in overall area. These results can assist in determining management strategies for the snowy plover, a threatened shore bird that nests on sandy beaches along the Florida Gulf coast.

Doyle, T.W.; Krauss, K.W.; Conner, W. H.; and From, A.S., 2010. Predicting the retreat and migration of tidal forests along the northern Gulf of Mexico under sea-level rise. Forest Ecology and Management, 259, 770-77.

Keywords: forests, habitat migration, modeling, mangroves, wetlands, Gulf of Mexico

Throughout the Gulf of Mexico mangrove forests are expanding at the expense of tidal freshwater forests. This study uses a mathematical model called SLOPE (Sea Level Over Proportional Elevation) to predict future coastal habitat change in the Gulf of Mexico from Texas to Key West. The model incorporates data on tidal ranges, existing habitat area, land form, and current and predicted sea-level change to predict future coastal habitat types. In south Florida, the model output suggests that mangrove forests will replace freshwater wetlands, minimizing the loss of total wetland habitat but greatly reducing biodiversity.

Geselbracht, L.; Freeman, K.; Kelly, E.; Gordon, D. R.; and Putz, F. E., 2011. Retrospective and prospective model simulations of sea level rise impacts on Gulf of Mexico coastal marshes and forests in Waccasassa Bay, Florida. Climatic Change, 107(1-2), 35-57.

Keywords: Big Bend, forests, habitat migration, modeling, wetlands

This work applies the Sea Level Affecting Marshes Model (SLAMM) to understand how sea-level change will impact land cover and wetland migration in the Big Bend region of Florida. The study attempts to verify the SLAMM predictions through hindcasting (comparing model results to measured historic data) using field data collected between 1984 and 2008. The verification showed that the model satisfactorily simulated past land cover patterns, especially the historic losses of coastal forest, transitional saltmarsh, saltmarsh, and inland freshwater marsh. However, hindcasting also showed substantial differences between specific model outputs and past conditions, indicating its predictive limitations. Effects of sea-level change were also projected into the future using scenarios of $0.6,1.0$, and 2.0 $\mathrm{m}$ sea-level rise by 2100 . The sea-level rise scenario of $0.6 \mathrm{~m}$ by 2100 estimated $97 \%$ of the 1973 coastal forest area would transition to saltmarsh or transitional saltmarsh by 2100 .

Houston, J.R. and Dean, R.G., 2011. Sea-level acceleration based on U.S. tide gauges and extensions of previous global-gauge analyses. Journal of Coastal Research, 27(3), 409-417.

Keywords: sea-level rise acceleration, sea-level rise prediction, tide gauge

The possible acceleration of sea-level rise is investigated using historical tide gauge data throughout the U.S., including Florida. Data records of 60-156 years were analyzed and projections focused on a subset of gauges with data from 1930-2010. Least squares quadratic analysis of gauge data was used to forecast rates of sea-level rise acceleration. Results indicate a slight decrease in the rate of sea-level rise acceleration from 0.0014 to $0.0123 \mathrm{~mm}$ per year within this time period.

Rahmstorf, S. and Vermeer, M., 2011. [Discussion of Houston, J. R. and Dean, R. G. 2011. Sea-level acceleration based on U.S. tide gauges and extensions of previous global-gauge analyses. Journal of Coastal Research, 27(3), 409-417.] Journal of Coastal Research, (27)4, 784-787.

Keywords: sea-level rise acceleration, sea-level rise prediction, tide gauge

This article presents a discussion of Houston and Dean's (2011) work (shown above). Rahmstorf and Vermeer state that there are three basic weaknesses of the Houston and Dean paper. 1) The use of a regional non-weighted approach does not consider global measurements. 2) The arbitrary cutoff of 1930 in the historical records may cause bias in the results and make sea-level rise appear to increase linearly rather than accelerating. 3) Rahmstorf and Vermeer expect acceleration to increase with increasing temperatures, but large temperature changes have yet to be seen. This is not accounted for in the Houston and Dean paper.

Houston, J. R. and Dean, R. G. 2011. [Rebuttal to Rahmstorf, S. and Vermeer, M., 2011. Discussion of: Houston, J.R. and Dean, R.G., 2011. Sea-level acceleration based on 
U.S. tide gauges and extensions of previous global-gauge analyses. Journal of Coastal Research, 27(3), 409-417.] Journal of Coastal Research, 27(4), 788-790.

Keywords: sea-level rise acceleration, sea-level rise prediction, tide gauge

This is a rebuttal to the discussion of Houston and Dean (2011) by Rahmstorf and Vermeer (2011) (shown above). Here, Houston and Dean argue that the time-based approach that they used to analyze changes in sea level is a standard and acceptable method. They assert that the method is not inferior to the empirical method presented by Rahmstorf and Vermeer, and that Rahmstorf and Vermeer's figure based on empirical methods does not exhibit the good agreement with projected and measured sea-level rise acceleration that they claim it does.

Krauss, K. W.; From, A. S.; Doyle, T.W.; Doyle, T.J.; and Barry, M., 2011. Sea-level rise and landscape change influence mangrove encroachment onto marsh in the Ten Thousand Islands region of Florida, USA. Journal of Coastal Conservation, 15(4), 629-638.

Keywords: habitat migration, mangroves, Ten Thousand Islands

This paper maps changes in mangrove land cover between the Gulf of Mexico and the Ten Thousand Islands area. The study covers a period of 78 years between 1927 and 2005. In 2005 there were 7,281 hectares (ha) of mangroves, 1,878 ha more than in 1927 . This represents a $35 \%$ increase in mangrove land cover in the study area. The authors attribute the increase to sea-level rise, but also note other anthropogenic impacts. For example, waterway construction has increased tidal influences in the area and possibly enhanced the dispersal of mangrove propagules. Additionally, changes in fresh overland runoff may also be contributing to the change in land cover. The authors state that understanding the mechanisms responsible for mangrove expansion can offer options to managers striving to conserve freshwater marshes.

Muhs, D.R.; Simmons, K.R.; Schumann, R.R.; and Halley, R.B., 2011. Sea-level history of the past two interglacial periods: new evidence from $U$-series dating of reef corals from south Florida. Quaternary Science Reviews, 30(5-6), 570-590.

Keywords: Florida Keys, historic sea-level rise
This research provides new data estimating the timing and degree of sea-level change during the Last Interglacial Period in Florida. The Last Interglacial Period (occurring approximately 120,000 years ago) is considered to be the last time that global temperatures were warmer than the present. Fossil corals from Key Largo limestone were aged using uranium radio-dating. Results show that for at least 9,000 years, sea level was higher than the present level during the Last Interglacial Period. Samples from fossil reefs in the Florida Keys show ages of approximately 200,000 years, indicating sea levels at or above present-day levels. Both the Key Largo limestone and the Miami limestone measurements indicate that sea level during the Last Interglacial Period was approximately 6.6-8.3 $\mathrm{m}$ higher than present day sea level.

Obeysekera, J.; Irizarry, M.; Park, J.; Barnes, J.; and Dessalegne, T., 2011. Climate change and its implications for water resources management in south Florida. Stochastic Environmental Research and Risk Assessment, 25(4), 495-516.

Keywords: Everglades, historic sea-level rise, modeling, storms

This work looks at historical records and climate change projections to understand the impacts of climate change on the Everglades ecosystem, as well as the drivers that are most important for influencing that system. Analysis shows no trends in long-term (1913-2008) or recent (1950-2007) rainfall and temperature in Florida. However, global climate models o not capture regional characteristics of rainfall and temperature in this area. Data from Key West indicates an increased frequency and variance of extreme sea level events between 1961 and 2008 when compared to 1913-1960. A sensitivity analysis showed that important drivers for the Everglades ecosystem include rainfall, evapotranspiration, sea-level change along the southern tip, and changes in salinity.

Park, J.; Obeysekera, J.; Irizarry, M.; Barnes, J.; Trimble, P.; and Park-Said, W., 2011. Storm surge projections and implications for water management in South Florida. Climatic Change, 107(1-2), 109-128.

Keywords: Key West, Mayport, Pensacola, storms, tide gauge

This research analyzed long-term tidal records to determine storm surge occurrence in Key West, Pensacola, and Mayport. The nontidally influenced 50 -year return period storm surge was found to be $0.5 \mathrm{~m}$ high in Key West, and $1.1 \mathrm{~m}$ high in Mayport and Pensacola. Using predicted 
eustatic (global) sea-level change scenarios and the Atlantic Multidecadal Oscillation (AMO) index, future storm surge return periods were predicted. Forecasts show a significant condensing of the return period of storm surges, such that a 1-in-50-year storm surge could become a 1-in-5-year storm surge. These results are discussed within the context of water management in Florida.

Saha, A.K.; Saha, S.; Sadle, J.; Jiang, J.; Ross, M.S.; Price, R.M.; Sternberg, S.L.O.; and Wendelberger, K.S., 2011. Sea level rise and south Florida coastal forests. Climatic Change, 107(1-2), 81-108.

Keywords: Everglades, forests, inundation, mangroves, modeling

This paper proposes that sea-level rise will negatively impact coastal hardwood hammocks and buttonwood forests within Everglades National Park before they are actually inundated with seawater. These systems are reliant upon precipitation, which provides freshwater to the vadose zone of the soil. The vadose zone is expected to be impacted by saltwater intrusion before surface water inundation due to a rising water table and drought conditions. The authors used the mangrove-hammock model to simulate the response of hardwood hammocks and mangroves to sea-level rise. Through this work, 21 species in the Everglades National Park are identified as being threatened by sea-level rise. Restoring freshwater inflow to the Everglades is one option to mitigate these effects, at least in the short-term.

Titus, J.G. and Richman, C., 2001. Maps of lands vulnerable to sea level rise: modeled elevations along the U.S. Atlantic and Gulf Coasts. Climate Research, 18(3), 205-228.

Keywords: Everglades, inundation, remote sensing, Gulf of Mexico, Atlantic coast

Mapping predictions of coastal sea-level rise impacts requires both high resolution elevation data of land and water surfaces and models of coastal processes (erosion, marsh accretion, sedimentation, etc.). This paper presents large-scale and small-scale maps of coastal land elevation along the U.S. Atlantic coast and Gulf of Mexico using the highest level of accuracy currently available by combining several data sources. Past limitations of coastal maps are discussed. For example, the widely available 7.5-minute USGS quadrangle maps use a wide contour interval (1.5 $\mathrm{m}$ ), and most are benchmarked by the National Geodetic Vertical Datum from 1929. Using this outdated benchmark creates a $10-20 \mathrm{~cm}$ inaccuracy in these maps. Light
Detection and Ranging (LIDAR) can increase accuracy but can be cost-prohibitive. By combining coastal data from USGS and NOAA, the authors estimate that the area of land below the $1.5 \mathrm{~m}$ contour in south and southwest Florida is actually $8,744 \mathrm{~km}^{2}$, almost double the area presented in the 1990 EPA report to congress. This is mainly due to the inclusion of additional NOAA shoreline data and higher estimations of open water in the Everglades than previously used. The report estimates that approximately one-third of the Everglades is below $1.5 \mathrm{~m}$, and half of Everglades National Park is within $0.3-0.6 \mathrm{~m}$ of sea level.

\section{Walton, T.L., 2007. Projected sea level rise in Florida. Ocean Engineering, 34, 1832-1840.}

Keywords: modeling, sea-level rise acceleration, sea-level rise prediction, tide gauge

This paper addresses the rate of sea-level change in Florida using a model based on historic tide gauge data. It discusses scenarios wherein sea level rises at a constant rate and scenarios wherein the rate of sea-level rise is accelerating. Tide gauge data from five sites in Florida between 1941 and 2005 are used to fit a statistical model. The model produced projections for future sea-level rise until the year 2080.

Three models were compared assuming a first order, second order, and exponential relationship. Results indicate that sea level will rise faster than past projections using straight trend lines. These results also show a maximum sea-level rise of $0.36 \mathrm{~m}$ by 2080 .

Wanless, H.R.; Parkinson, R.W.; and Tedesco, L.P., 1994. Sea level control on stability of Everglades wetlands. In Davis, S.M. and Ogden, J.C. (ed.), Everglades: the ecosystem and its restoration. St. Lucie Press, Delray Beach, Florida, USA. 199-224.

Keywords: Everglades, habitat migration, historic sea-level rise, wetlands, salinity

The Everglades formed over the past 3,200 years during a period of relatively slow sea-level rise, a rate averaging $4 \mathrm{~cm}$ per 100 years. This slow rate allowed sediments and organic matter to accrete vertically. Before this period of wetland formation, sea-level rise was faster $(23-50 \mathrm{~cm}$ per 100 years), which was too fast for the development of stable coastal swamp, marl, or sand ecosystems. Current sea-level rise in the Everglades is 3-4 mm/ per year $(20-40 \mathrm{~cm}$ per 100 years). This increased rate is already impacting the Everglades by accelerating erosion along shore margins, causing landward migration of saline wetlands and increasing saltwater intrusion to surface and ground waters. 
According to the authors, if sea-level change continues at the present pace or accelerates, these impacts will worsen and be exacerbated by storms.

Zhang, K. Q.; Douglas, B.C., and Leatherman, S.P., 2000. Twentieth-century storm activity along the U.S. East Coast. Journal of Climate, 13, 1748-1761.

Keywords: Mayport, storms, tide gauge

Speculation that climate change is causing increased storm activity along the U.S. Atlantic coast was investigated using water level data from tide gauges and tropical storm tracking data. Several short-comings of past research indicating an increase in storm frequency and intensity are discussed, such as 1) the lack of long-term data (the most extensive record previously used was only 25 years), 2 ) the use of coastal damage reports that do not account for increased coastal development over time, 3) the difficulty in separating the contribution of astronomical tides from storm surges, and 4) the importance of distinguishing tropical storms (hurricanes) from extratropical storms (northeasters). Results indicate that Mayport has a greater occurrence of tropical storms than extratropical storms. There is significant inter-decadal variation in storm activity along the entire East Coast, with the period of greatest storm frequency and intensity occurring from the late 1950 s to the early 1960s. This study found no "discernible long-term secular trend in storm activity during the twentieth century."

Zhang, K.; Dittmar, J.; Ross, M.S.; and Bergh, C., 2011. Assessment of sea level rise impacts on human population and real property in the Florida Keys. Climatic Change, 107(1-2), 129-146.

Keywords: Florida Keys, inundation, remote sensing, sea-level rise prediction

Remote sensing, using LIDAR digital elevation maps (DEM), was used to estimate the inundation of the Florida Keys in 2100 under current sea-level change predictions. The simulation shows that a $0.6 \mathrm{~m}$ rise in sea level would inundate $70 \%$ of the Keys' land area, and a $1.5 \mathrm{~m}$ rise in sea level would inundate $91 \%$ of the land area. Inundation of populated areas and implications for real estate are discussed. Results indicate the lower Keys are more vulnerable to sea-level rise than the upper Keys. The authors highlight the nonlinear behavior of sea-level change, inundation, and tipping points.
Zhang, K., 2011. Analysis of non-linear inundation from sea-level rise using LIDAR data: a case study for South Florida. Climatic Change, 106(4), 537-565.

Keywords: Broward County, Everglades, inundation, MiamiDade County, Palm Beach County, sea-level rise prediction, remote sensing

Remote sensing, using LIDAR digital elevation maps (DEM), was used to estimate the areas of Miami-Dade County, Broward County, Palm Beach County, and Everglades National Park inundated under predicted sea-level change. Sea-level rise scenarios of $0.5,1.0,1.5,2.0,2.5$, and $3.0 \mathrm{~m}$ by 2100 were considered. Results show inundation occurring at a non-linear rate due to regional topography. Thresholds, or tipping points, occur when sea-level rise reaches $1.25,1.5$ and $3.0 \mathrm{~m}$ in height. The author also compares the predictions of inundation using the two different elevation data sets available. The resolution of USGS DEM data resulted in 1.65 times more land inundation under the $1.5 \mathrm{~m}$ scenario than when the LIDAR data was used. Miami-Dade County was shown to be the most vulnerable area to sea-level change, followed by Broward and then Palm Beach counties. Results indicate catastrophic inundation in Miami-Dade and the Everglades National Park if sea level rises by $1.5 \mathrm{~m}$.

\section{Biological Science}

Aiello-Lammens, M. E.; Chu-Agor, M. L.; Convertino, M.; Fischer, R.A.; Linkov, I.; and Akcakaya, H.R., 2011. The impact of sea-level rise on snowy plovers in Florida: Integrating geomorphological, habitat, and metapopulation models. Global Change Biology, 17(12), 3644-3654.

Keywords: Gulf of Mexico, modeling, threatened and endangered species, wildlife habitat

The Snowy Plover (Charadrius alexandrinus) is a small shorebird that is listed as threatened in Florida. It lives and breeds on sandy beaches, salt flats, and river bars along the Gulf of Mexico. To assess the potential impact of sea-level change on suitable habitat for the Snowy Plover, the authors combined three types of computer models: a geomorphological model called SLAMM (Sea Level Affecting Marshes Model); a habitat model; and a demographic model that included species-specific factors such as carrying capacity, density-dependence, and dispersion. The model output predicts an increase in the probability of Snowy Plover extinction by 2100 from the current probability estimate of $7 \%$, to a $9 \%$ and $11 \%$ probability under scenarios of $1 \mathrm{~m}$ and $2 \mathrm{~m}$ sea-level rise, respectively. The model also predicts 
a decline in the minimum abundance of Snowy Plovers in 2100 from the current estimate of 97 individuals, to 77 individuals with a $1 \mathrm{~m}$ rise in sea level, and 70 individuals with a $2 \mathrm{~m}$ rise in sea level. This paper demonstrates the applications of using linked models for predicting species vulnerability to sea-level change, but warns that the model output includes significant uncertainty about the role of survival rate and fecundity in the predictions.

Chambers, L.G.; Reddy, K.R.; and Osborne, T.Z., 2001. Short-term response of carbon cycling to salinity pulses in a freshwater wetland. Soil Science Society of America Journal, 75(5), 2000-2007.

Keywords: greenhouse gases, salinity, wetlands

The wetlands that fringe the coast of Florida are very productive, accumulating large amounts of carbon stored in the organic-rich soils of these ecosystems. As sea level rises, saltwater encroaches inland and has the potential to change the biology of the wetland soils, especially the microbial populations that live in the soil. A change in soil microbial communities could reduce the stability of the accumulated carbon, subsequently releasing it into the atmosphere and adding to the concentration of atmospheric carbon dioxide $\left(\mathrm{CO}_{2}\right)$, a greenhouse gas. Using organic wetland soils collected near Cape Canaveral, this study shows that the chemical composition of saltwater (especially sulfate, a major ion in seawater) can accelerate the activity of some microbial populations in the soil, increasing the rate at which carbon is released from the soil in the short-term. When looking at the soil microbial community as a whole, the intrusion of low-salinity saltwater could cause the greatest increase in the rate of carbon loss from wetland soils because microbial activity is stimulated while the impact of salt-stress is still minimal.

Coleman, F.C., and Koenig, C.C., 2010. The effects of fishing, climate change, and other anthropogenic disturbances on red grouper and other reef fishes in the Gulf of Mexico. Integrative and Comparative Biology, 50(2), 201-212.

Keywords: fisheries, habitat migration, water quality, wildlife habitat, Gulf of Mexico

This study investigates how anthropogenic disturbances affect three fish species in the Gulf of Mexico: the shallowwater Atlantic goliath grouper (Epinephelus itajara), the red grouper (Epinephelus morio), and the tilefish (Lopholatilus chamaeleonticeps). Each of these species is considered an ecosystem engineer, or foundation species. Disturbances of greatest concern to the fisheries in the Gulf of Mexico are over fishing, red tides, oil and gas extraction/exploration, and climate change. With respect to climate change, sealevel change in particular may alter the biogenic foundation species or the autogenic ecosystem engineers. Because of the accelerated pace of sea-level change relative to historical changes, these foundation species may not be able keep pace with sea-level rise by migrating landward. Rising temperatures due to climate change may also cause shifts in ocean currents, nutrient availability, or larval success, and all of these things could impair these species' recruitment.

Desantis, L.R.G.; Bhotika, S.; Williams, K.; and Putz, F.E., 2007. Sea-level rise and drought interactions accelerate forest decline on the Gulf Coast of Florida, USA. Global Change Biology, 13(11), 2349-2360.

\section{Keywords: Big Bend, biological indicator, forests, habitat} migration, salinity

This paper documents the continuation of a 13-year study of declining coastal forest habitat near Waccasassa Bay in the Big Bend region of Florida (also reported on in Williams et al., 1999 and 2003). Sea-level rise in this area averaged $2.4 \mathrm{~mm}$ per year from 1939 to 2005 . Increasing tidal flooding and decreasing relative elevation are strongly correlated with a decline in forest species richness. Cabbage palm (Sabal palmetto) is the most salt-tolerant tree species in this area, but it was unable to survive when flooding frequency met or exceeded $46 \%$ of weeks in a given year. Southern red cedar (Juniperus virginiana), the second most salt-tolerant species, was eliminated when flooding frequency reached $23 \%$ of the weeks in a given year. The drought associated with La Niña (1998-2002) intensified water stress in all tree species, but was especially damaging to those trees already experiencing increased tidal flooding.

Fei, S. L.; Cox, J.; and Whittle, A., 2011. A perfect storm may threaten Florida panther recovery. Frontiers in Ecology and the Environment, 9(6), 317-318.

Keywords: threatened and endangered species, wildlife habitat

Although habitat loss and fragmentation due to human development remains the leading cause of the decline of the Florida panther (Puma concolorcoryi), sea-level change also poses a risk to the long-term survival of the species. Panther habitat, which is concentrated in southwest Florida, is low-lying and has a maximum elevation of about $12 \mathrm{~m}$ above sea level. Under conservative sea-level rise estimates ( $0.6 \mathrm{~m}$ by 2100 ), about $10 \%$ of the current panther habitat 
would become inundated. Under the $2 \mathrm{~m}$ by 2100 scenario, about $33 \%$ of panther habitat would be lost. The author encourages the consideration of sea-level change impacts when developing wildlife corridors and protected areas in SW Florida.

Gaiser, E.E.; Zafiris, A.; Ruiz, P.L.; Tobias, F.A.C., and Ross M.S., 2006. Tracking rates of ecotone migration due to salt-water encroachment using fossil mollusks in coastal south Florida. Hydrobiologia, 569(1), 237-257.

Keywords: biological indicator, Biscayne Bay, habitat migration, historic sea-level rise, mangroves, salinity, wetlands

Saltwater intrusion and changes in the management of freshwater supplies since the 1900s in south Florida have altered the salinity regime of Biscayne Bay's coastal wetlands. Interested in the migration of coastal ecotones (the transition area between two different types of ecosystems or habitats) over time, this study used mollusk community composition as a biological indicator for paleo-environmental conditions. Two-meter-deep sediment cores were collected throughout the coastal wetlands and analyzed for relic mollusk shells, soil characteristics, and the distribution of carbon and lead isotopes (used to date the soil). The study indicates that soil is becoming deeper in the mangrove fringe compared to the inland freshwater marsh, which is considered to be a result of higher sedimentation and accretion rates in the mangrove habitat. Mollusk species composition was a reliable indicator of historic salinity in the region. The study also concludes that the ecotone between mangroves and freshwater marshes is migrating landward at a rate of 2 to $4 \mathrm{~m}$ per year, 1-2 orders of magnitude faster than the migration rate before 1940. This equates to a 450-m westward expansion of the mangrove habitat, at the expense of the freshwater marsh habitat, in the past 60 years. Mangrove habitat in this area appears to be keeping pace with sea-level change through vertical accretion and is even expanding landward.

\section{Maschinski, J.; Ross, M.S.; Liu, H.; O’Brien, J.; von Wettberg, E.J.; and Haskins, K.E., 2011. Sinking ships: conservation options for endemic taxa threatened by sea level rise. Climatic Change, 107(1/2), 147-167.}

Keywords: Florida Keys, threatened and endangered species, wildlife habitat

This study evaluates options for conserving rare and endemic species in the face of sea-level change using the Florida Keys as a model system. The Florida Keys face a significant risk of inundation with rising sea level and a loss of habitat that is critical for several threatened species. This paper investigates the conservation options for two species of plants: the Big Pine partridge pea (Chamaecrista lineata) and the sand flax (Linum arenicola) as well as two species of animals: the Key deer (Oedocoileus virginianus clavium) and the Lower Keys marsh rabbit (Sylvilagus palustris hefneri). The authors advocate for a diverse multi-tiered approach to conservation where short-term and long-term strategies are implemented.

Pearlstine, L.G., Pearlstine, E.V., and Aumen, N.G., 2010. A review of the ecological consequences and management implications of climate change for the Everglades. Journal of the North American Benthological Society, 29(4), 1510-1526.

Keywords: Everglades, threatened and endangered species, wildlife habitat

Florida's Everglades is home to 36 vertebrate species and 26 plant species that are listed as endangered, threatened, or candidate species on the Federal Endangered Species Act. This paper presents general ecosystem responses to climate change and sea-level rise. It describes the vegetation communities of the Everglades National Park. It also discusses peatlands, carbon sequestration, fishes, amphibians, reptiles, birds, and evolutionary adaptation, as well as presenting adaptive conservation strategies. Some of these strategies include: restoration, reducing anthropogenic stresses, habitat conservation, assisted propagation, breeding, and migration, utilizing captive populations, and accepting change.

Rizkalla, C.E. and Savage, A., 2011. Impact of seawalls on loggerhead sea turtle (Caretta caretta) nesting and hatching success. Journal of Coastal Research, 27(1), 166-173.

Keywords: coastal armoring, beaches, threatened and endangered species

This paper investigates the effects of seawalls on loggerhead turtle nesting and hatching success. The impact of armoring structures is relatively well understood with respect to beach ecosystems. However, the impact of sea walls on sea turtle nesting is less clear. To investigate this question, the authors observed sea turtle nesting behavior at a seaward wall and a landward wall in Florida. Nesting patterns indicate that the erosion at seawalls decreases the number of turtles that attempt to nest in that area. Additionally, the nests that are constructed by seawalls are more at risk for washing away in storms. As sea-level change threatens 
human development along the coast, protective measures such as armoring the shoreline with seawalls are expected to increase. According to the authors, this will likely decrease the area of suitable nesting habitat for loggerhead turtles, an endangered species.

Ross, M.S.; Meeder, J.F.; Sah, J.P.; Ruiz, P.L.; and Telesnicki. G.J., 2000. The southeast saline Everglades revisited: 50 years of coastal vegetation change. Journal of Vegetation Science, 11(1), 101-112.

Keywords: biological indicator, Everglades, habitat migration, mangroves, salinity, wetlands

In the 1940s a transitional zone of low vegetation productivity, dubbed the "white zone" due to the exposure of bare soil, was identified in aerial photographs of the southeastern Everglades. Vegetation in the southeastern Everglades occurs in belts parallel to the coastline that are defined mainly by the plant species' tolerance to salinity. The lower belt (nearest the coast) is dominated by red mangroves (Rhizophora mangle) and rushes (Eleocharis spp.). This is followed by the white zone, where mangrove propagules are sparse and bare soil abounds, and finally the upper belt, which is dominated by sawgrass (Cladium jamaicense). Using the white zone as a proxy for the location of the saltwater boundary, this paper compares the location of that boundary in 1940 to the location in the mid-1990s using aerial photographs. Results indicate that the interior boundary of the white zone migrated landward an average of $1.46 \mathrm{~km}$, correlating with the rate of sea-level change recorded using tide gauges in Key West. This suggests that sea-level rise has altered coastal vegetation patterns over the 50 years that the study examined, and indicates that related processes, such as soil accretion, have also occurred. The paper also documents localized differences in the rate of landward migration of the white zone based on local freshwater management activities. For example, canal systems that limit freshwater delivery increase the rate of landward movement of the white zone.

Roy, M.; Martin, J.B.; Cherrier, J.; Cable, J.E.; and Smith, C.G., 2010. Influence of sea level rise on iron diagenesis in an east Florida subterranean estuary. Geochimica et Cosmochimica Acta, 74(19), 5560-5573.

\section{Keywords: groundwater, salinity, Indian River, water quality}

Subterranean estuaries are a transition area between hypoxic fresh groundwater and oxic seawater. It is hypothesized in this paper that iron reactions will change as a result of sea-level rise and the oxic saltwater that it will introduce. Using samples from porewater and sediments in the Indian River Lagoon and a site 250 m offshore, concentrations of iron, sulfur, and dissolved organic carbon were measured. Iron concentrations increased from $0.5 \mu \mathrm{M}$ to $286 \mu \mathrm{M}$ between the shoreline and the freshwater/saltwater boundary. In the Indian River Lagoon, iron transformation generally occurs at the freshwater/saltwater boundary and may be important for primary productivity. Long-term changes in the location of the boundary in response to sea-level change may have a significant effect on local geochemistry by increasing the flux of iron and possibly increasing ecosystem productivity.

Seavey, J. R.; Pine, W. E. III; Frederick, P.; Sturmer, L.; and Berrigan, M., 2011. Decadal changes in oyster reefs in the Big Bend of Florida's Gulf Coast. Ecosphere, 2(10), 1-14.

Keywords: Big Bend, fisheries, salinity

The coastal zone along the Big Bend of Florida supports an established and highly productive area of oyster reefs with great economic and ecological importance. This study uses aerial photographs of the coastal zone from 1982 to 2010 to assess the health and size of oyster reefs in four key areas. Results indicate a significant decline in the size of all the reefs investigated, with offshore reefs (1000 to $2600 \mathrm{~m}$ from shore) losing the greatest area ( $88 \%)$, followed by nearshore reefs (140 to $1000 \mathrm{~m}$ offshore; $61 \%$ decline) and inshore reefs ( 0 to $140 \mathrm{~m}$ offshore; $50 \%$ decline). The low-density development of the area and harvest regulations enacted in 1987 reduces the likelihood that human damage is the major cause for the observed decline. The authors hypothesize that sea-level rise (tide gauges documented a $5 \mathrm{~cm}$ rise in the study area over the 28 -year period) may have increased salinity, especially on the offshore reefs, encouraging more predation and possibly increasing sedimentation and wave energy, leading to the decline of the oyster reefs.

Willard, D.A. and Bernhardt, C. E., 2011. Impacts of past climate and sea level change on Everglades wetlands: Placing a century of anthropogenic change into a lateHolocene context. Climatic Change, 107(1-2), 59-80.

Keywords: biological indicator, Everglades, habitat migration, historic sea-level rise, wetlands

Historical sea-level change, climate variability, and anthropogenic changes are evaluated in reference to their impacts on hydrology and wetland plant ecology in the Everglades. The Everglades were formed by the accumulation of freshwater peat beginning 6,000 to 7,000 years ago 
when sea level was $6.2 \mathrm{~m}$ below its present level. By 5,000 years before present, the area from Lake Okeechobee to the Florida Keys was covered with peat formed by sawgrass and water lily communities. Three thousand years ago sea-level rise slowed, the coastline of south Florida stabilized, and mangrove communities developed along the coast. Evidence from pollen show that regional droughts occurring 400 to 1,000 years ago initiated the development of the ridge/slough topography and tree islands that we see today. Recent anthropogenic changes to the Everglades hydrology via flow alterations, wetland compartmentalization, and sea-level rise, have resulted in unprecedented rates of change in the ecosystem. Evidence of these changes can be seen in soil oxidation, soil subsidence, and the alteration or loss of specific habitats and vegetation.

\section{Williams, K.; Ewel, K.C.; Stumpf, R.P.; Putz, F.E.; and Workman, T.W., 1999. Sea-level rise and coastal forest retreat on the west coast of Florida, USA. Ecology, 80(6), 2045-2063.}

Keywords: Big Bend, biological indicator, forests, habitat migration

The Big Bend region of Florida consists of a low-lying carbonate coast with minimal human disturbance. Since the 1930s, changes in the composition and coverage of coastal forest communities have been documented, including shrinking tree islands within the coastal marshes and the landward retreat of the coastal forest edge. This study tested the hypothesis that forest community changes are a result of sea-level change and the differential flooding and salt tolerance of local plant species. Results indicate a negative correlation between tidal flooding frequency, tree species richness, and tree recruitment success. Coastal forests are developing a zonation pattern based on the salt tolerance of seedlings, with mature trees remaining viable long after regeneration has ceased in some stands because older plants are able to tolerate more salt and flooding stress than seedlings. According to the authors, the rate of forest retreat in this area is generally consistent with the rate of local sea-level change.

Williams, K.; MacDonald, M.; and Sternberg, L.D.L., 2003. Interactions of storm, drought, and sea-level rise on coastal forest: A case study. Journal of Coastal Research, 19(4), 1116-1121.

Keywords: Big Bend, forests, storms

Conducted at the same sites along the Big Bend coastline as the Williams et al. (1999) study, this paper addresses the impact of storms and severe droughts on coastal forest mortality. A 1993 storm, which was accompanied by a $2-3 \mathrm{~m}$ storm surge and high winds, was shown to be more damaging to southern red cedar (Juniperus virginiana) populations than to the co-dominant cabbage palm (Sabal palmetto). The storm-related increase in mortality of Juniperus lasted for two years following the storm. The storm uprooted trees, deposited about $2 \mathrm{~mm}$ of sandy silt, left piles of seaweed and other marine debris, and eroded loose soil. The drought also appeared to target Juniperus, causing increased mortality, especially in areas of previously documented decline due to sea-level change.

\section{Social Science}

Bloetscher F.; Meeroff, D.E.; Heimlich, B.N.; Brown, A.R.; Bayler D.; and Loucraft M., 2010. Improving resilience against the effects of climate change. Journal of the American Water Works Association, 102(11), 36-46.

\section{Keywords: Broward County, groundwater, Miami-Dade County, utilities}

This paper summarizes a history of freshwater supply challenges in southeast Florida. The area receives 60 inches of rain per year, but $70 \%$ of that rain occurs during only four months of the year (June-Sept.). Water storage is made difficult by the low topography (more than $50 \%$ of the urban areas of Miami-Dade and Broward counties are less than 5 feet above mean sea level), a high water table, and competing demands between a population of 5 million people and the Everglades, which require significant freshwater flow to remain healthy. The development of southeast Florida was made possible by reducing groundwater levels through the construction of extensive canals, pumping stations, and water control structures. Sea-level rise in this highly porous geology will be accompanied by a higher groundwater table, leading to more extensive flooding during rain events and a higher risk of seawater contaminating the Biscayne aquifer, the freshwater source for the urban residents. The authors outline several ideas of how water utilities (potable water supply, wastewater, and stormwater) in southeast Florida may be able to adapt to sea-level change while still meeting the demands of urban residents and natural areas. The concepts discussed focus on minimizing saltwater intrusion and maintaining adequate freshwater supply. Ideas are presented as an "adaptation toolbox" and include stormwater pumping stations, increased funding for water conservation programs, armoring the sewer system to prevent saltwater inflow, and relocating high risk wellfields. 
Bloetscher, F.; Meeroff, D.E.; Heimlich, B.N.; Brown, A.R.; Bayler, F.; Tim, G.; Wood, N.; and Yarnal, B., 2010. Stakeholder perspectives on land-use strategies for adapting to climate-change-enhanced coastal hazards: Sarasota, Florida. Applied Geography, 30(4), 506-517.

Keywords: citizen involvement, land-use planning, Sarasota, storms

Sustainable land-use planning must account for a number of stressors, including population growth, extreme climatic events, and sea-level change. This research investigates land-use planning considerations through the implementation of a community workshop in Sarasota County. Participants in the workshop represented a broad spectrum of stakeholders, including individuals from business, environmental interests, emergency management, government, and planning. Citizens were divided into focus groups where they conducted mapping exercises using the county's current 2050 comprehensive land-use plan. Present and projected storm surge hazard areas based on various sea-level change scenarios were discussed. Common agreement was reached on the need to increase resilience to storm surge hazards and explore alternatives for dealing with future projections of storm surge hazard zones.

Choate, J. F., 2011. Sea level rise planning for Florida's nuclear energy infrastructure: a wait and "sea" approach?” Sea Grant Law and Policy Journal, (4)1, 28-60.

Keywords: inundation, utilities

This paper investigates the risks associated with sea-level rise on existing and proposed nuclear power plants in Florida. Federal, state, and local permitting processes for nuclear power plants in Florida are discussed. The locations of current and planned nuclear power plants are described and the inclusion of sea-level change considerations in those plans is investigated. Existing tools and strategies for responding to sea-level change are also reviewed. According to the author, state agencies are discussing moving sites for nuclear power plants inland in preparation for sea-level rise. On the other hand, the Federal Nuclear Regulatory Commission was found lacking in its planning for sea-level change and the author asserts that the sea-level change scenarios used by the commission may be too conservative.

Christie, D.R., 2009. Of beaches, boundaries, and SOBs. Journal of Land Use \& Environmental Law, 25(19), 19-75.

Keywords: beach nourishment, beaches, legislation, private property rights, Gulf of Mexico
Florida's Beach and Shore Preservation Act is discussed in detail, including the rationale behind the act, the rights of the state, and the rights of private property owners. The provisions of the act are similar to common law in terms of the protection of coastal property rights and access to water, but the act also strives to establish a fixed boundary between private lands and public lands. The act allows the state government to restore and nourish beaches. This change was prompted by constant beach erosion, which highlighted for policy makers the vulnerability of coastal populations and the state's beach-based economy. The article highlights that setting a fixed boundary on restored beaches between private and sovereign land would serve to unequivocally establish areas for public beach access. The author recognizes that private land ownership fosters a sense of stewardship, but argues that local governments must take responsibility for regulating and managing the use and access of beaches before conflicts occur.

Christie, D. R., 2011. Sea level rise and gulf beaches: The specter of judicial takings. Journal of Land Use \& Environmental Law, 26(2), 313-325.

Keywords: beach nourishment, beaches, legislation, private property rights

The question of whether the Beach and Shore Preservation Act's (BSPA) authorization of government-run beach nourishment projects constitutes a regulatory taking of common law property rights is discussed in this article. When the Florida Supreme Court upheld the BSPA's abrogation of the common law right of accretion to private property, it did so on the grounds that accretions are a future contingent right not implicated by the act's nourishment provisions. It also asserted that the common law right of access to the water is explicitly preserved under the BSPA. The case was then taken to the U.S. Supreme Court in Stop the Beach Renourishment, Inc. v. Florida Department of Environmental Protection. The U.S. Supreme Court also upheld the validity of the act, but Justice Scalia raised the issue that there should be no distinction under the Fifth and Fourteenth Amendment Takings Clauses between what constitutes a traditional taking, and what constitutes a regulatory taking by act of government regulation. With the regulatory takings test in favor of government regulation, Justice Scalia suggests that the Supreme Court may adopt a less favorable regulatory takings test in the future, which would impose a massive financial burden on the states.

Fischman, A., 2012. Preserving legal avenues for climate justice in Florida post-American electric power. Florida Law Review, 64, 295-304. 
Keywords: greenhouse gases, legislation, vulnerability

In American Electric Power Co. v. Connecticut, the U.S. Supreme Court ruled that the Clean Air Act and EPA regulations preempted any federal common law right to force coal-burning power plants to reduce carbon dioxide emissions that are directly related to global warming and sea-level change. The court did not, however, address state common law causes of action. Populations in Florida are particularly vulnerable to sea-level change and may be interested in legal pathways to force mitigation of climate change. This interest could include participating in the administrative rulemaking process to limit carbon emissions. However the ruling currently does not address higher magnitude harm that climate-vulnerable populations are likely to face under increasing sea-level rise. According to the author, Florida courts may be able to facilitate compensation and relocation for climate-vulnerable populations by upholding claims under state common law nuisance principles.

Flugman, E.; Mozumder, P.; and Randhir T., 2012. Facilitating adaptation to global climate change: perspectives from experts and decision makers serving the Florida Keys. Climactic Change, 112(3-4), 1015-1035.

Keywords: Florida Keys

This paper investigates the resources, institutional frameworks, and leadership available for addressing sea-level change in the Florida Keys. According to the authors, though there is a shift in the political and public awareness toward recognizing sea-level change, the resources that are necessary for addressing the challenge are lacking. The findings suggest that adaptation strategies can be implemented locally. Potential funding sources in the area are explored, including a proposed "Community Adaption Fund."

Frazier, T.G.; Wood, N.; and Yarnal, B., 2010. Stakeholder perspectives on land-use strategies for adapting to climate-change-enhanced coastal hazards: Sarasota, Florida. Applied Geography, 30(4), 506-517.

Keywords: citizen involvement, land-use planning, Sarasota, storms

Sustainable use planning must account for a number of stressors, including population growth, extreme climatic events, and sea-level change. This research investigates land-use planning considerations through the implementation of a community workshop in Sarasota County. Participants in the workshop represented a broad spectrum of stakeholders, including individuals from business, environmental interests, emergency management, government, and planning. Citizens were divided into focus groups where they conducted mapping exercises using the county's current 2050 comprehensive landuse plan. Present and projected storm surge hazard areas based on various sea-level change scenarios were discussed. Common agreement was reached on the need to increase resilience to storm surge hazards and explore alternatives for dealing with future projections of storm surge hazard zones.

Frazier, T.G.; Wood, N.; Yarnal B.; and Bauer, D.H., 2010. Influence of potential sea level rise on societal vulnerability to hurricane storm-surge hazards, Sarasota County, Florida. Applied Geography, 30(4), 490-505.

Keywords: land-use planning, Sarasota, storms, utilities, vulnerability

Current research is split on whether recently observed hurricane frequency is related to climate change or multidecadal variations. Regardless, sea-level rise is predicted to increase the land area and population in the hazard-zone for storm surges. This paper investigated how the current storm-surge hazard zones in Sarasota County would need to be changed to account for a $120 \mathrm{~cm}$ increase in sea level. The authors found that a $120 \mathrm{~cm}$ increase in sea level will double the size of the population and number of municipal utilities at risk from a storm surge. Additionally, the current hazard zone for each category of hurricane could roughly be applied to the category beneath it under future sea level conditions (e.g., the zone delineated as hazardous for a Category 2 hurricane will be at risk for a Category 1 hurricane under predicted sea-level rise).

Jancaitis, K.M., 2008. Florida on the Coast of Climate Change: Responding to Rising Seas. Environs: Environmental Law and Policy Journal, 31, 157-194.

Keywords: greenhouse gases, land-use planning, vulnerability

Florida's vulnerability to sea-level rise through the loss of land, infrastructure, coastal ecosystems, natural buffers, agriculture, and tourist revenue are discussed in this article. The author suggests the need for a combination of coping methods including prevention, mitigation, and adaptation to adequately address the problem of sea-level change in Florida effectively and efficiently. The paper also asserts the need to prevent future sea-level change by reducing greenhouse gas emissions through the creation of a carbon tax, developing alternative energy resources, and increasing energy efficiency. The use of forests and wetlands as carbon 
sinks could also help to reduce atmospheric greenhouse gas concentrations. According to the author, advanced planning is essential, including infrastructure protection, the creation of coastal wetland buffer zones, and decreasing coastal development practices. Utilizing alternative land management practices will allow for adaptations to sea-level change, but complete abandonment of high-risk property may also be necessary.

\section{Martin, J.; Fackler, P.; Nichols, J.; Lubow, B.; Eaton, M.;} Runge, M.; Stith, B.; and Langtimm, C., 2011. Structured decision making as a proactive approach to dealing with sea level rise in Florida. Climatic Change, 107(1), 185-202.

Keywords: land-use planning, modeling, threatened and endangered species

This research applies structured decision making (SDM) to the management and conservation challenges facing Florida due to sea-level change. SDM presents an analytical decision framework that allows a rigorous format for natural resources management. SDM's goal is to identify optimal decisions given current knowledge and management objectives. Whereas most applications of SDM are to stationary systems, this research acknowledges the non-stationarity of the sea-level change problem. As such, management objectives may change and uncertainty exacerbated. This particular application of SDM provides a quantitative model for species management focusing on the Florida manatee. In this model a wetland provides both water for agriculture and habitat for the manatee. The objectives of the model are to maximize the outflow for agricultural purposes and, at the same time, provide a minimum area of habitat.

Marshal, A.; Robinson, L.; and Owens, M.A., 2011. Coastal construction trends in response to coastal erosion: An opportunity for adaptation. Journal of Coastal Conservation, (15) 1, 61-72.

Keywords: Apalachicola, beach nourishment, beaches, private property rights

Half of the sandy beaches in coastal Florida are classified as critical erosion areas. This article investigates how trends in coastal development have responded to the designation of these critical erosion areas. Coastal construction permitting trends between 1987 and 2007 were analyzed spatially and temporally. Three counties, Franklin, Gulf, and Bay, were selected for study based on their proximity to the Apalachicola National Estuarine Research Reserve. The study concludes that clusters of coastal development have not been reduced or redirected based on a designation as a critical erosion area. The practice of beach nourishment in Florida requires that the beach to be nourished must lie within a critical erosion designation. According to the author, this implies that the designation may be subject to external pressures from property owners and local governments.

\section{Nolan, J. R. and Bacher, J., 2007. Zoning and land use planning. Real Estate Law Journal, 38, 211-238.}

\section{Keywords: citizen involvement, land-use planning}

This paper describes the benefits of developing a local, citizen-based task force to assist in addressing land use and zoning consideration in communities facing climate change impacts. According to the authors, the task force should be composed of representatives from all stakeholders in the community and should allow for public participation. Examples of such task forces include, 1) the Miami-Dade Climate Change Advisory Task Force, which advised and provided technical assistance to the Board of County Commissioners on issues such as county management, zoning, infrastructure, and planning and, 2) the Governor's Action Team on Energy and Climate Change (est. 2007), which reports on adaptation strategies to climate change that minimize adverse impacts on society, public health, the economy, and the natural environment. The authors recommend that all local governments in Florida consider sea-level rise in any land use changes occurring at an elevation less than 10 feet above sea level, that high resolution topographic maps be created with detailed one-foot intervals, and that long-term implications of planning strategies be considered instead of the usual 10- to 20 -year time frame.

\section{Noss, R. F., 2011. Between the devil and the deep blue sea: Florida's unenviable position with respect to sea level rise. Climatic Change, 107(1-2), 1-16.}

\section{Keywords: citizen involvement, vulnerability}

This paper introduces a special edition of the Journal, "Climatic Change" that includes a series of articles on the impacts of sea-level rise on Florida. The special edition comprises the results of a symposium held in 2010 at the Archbold Biological Station sponsored by the Florida Institute for Conservation Science. Symposium participants concluded that planning for sea-level rise should incorporate both anthropogenic and natural issues in concert. The author states that to date, literature has largely focused on 
rising temperatures and decreasing moisture rather than on sea-level rise. The author concludes that the main lesson to be learned from the research in this special edition is that sea-level rise, population growth, development in coastal areas, and habitat fragmentation all make human and natural systems very vulnerable in the state of Florida.

Pace, N.L., 2011. Wetlands or seawalls? Adapting shoreline regulation to address sea level rise and wetland preservation in the Gulf of Mexico. Journal of Land Use \& Environmental Law, 26(2), 327-363.

Keywords: beach nourishment, beaches, coastal armoring, legislation, private property rights, wetlands, Gulf of Mexico

This report summarizes the ongoing debate in Florida between private property owners and the government regarding beach-front development, shoreline protections, and public access. Private property owners are increasingly installing hard coastal armament (seawalls, bulkheads, etc.) to protect their land against erosion and storms, but the state is beginning to limit permits for such armoring in favor of protecting wetlands and natural lands. The author asserts that hard structures will have immense long-term ecological effects along the Gulf of Mexico by accelerating the loss of wetlands and estuarine habitats that provide critical ecosystem services. The paper discusses the current approach to shoreline protection and introduces an alternative, called "living shorelines," as a method of protecting the coast using natural systems. The paper discusses some of the legislation pertaining to this issue, such as Florida's Coastal Construction Control Line, an effort to regulate buildings on coastal properties, and the Stop the Beach Renourishment, Inc. v. Dept of Envtl. Prot., 130 S. Ct. 2592 (2010) case, in which the U.S. Supreme Court denied beachfront property owners an injunction against the state for beach nourishment of submerged land. The author asserts that disputes involving Florida shoreline regulation are likely to increase as the effects of sea-level change become more serious.

Parkinson, R. and McCue, T., 2011. Assessing municipal vulnerability to predicted sea-level rise: City of Satellite Beach, Florida. Climatic Change, (107)1, 203-223.

Keywords: citizen involvement, inundation, Satellite Beach, utilities, vulnerability

The City of Satellite Beach authorized a study in 2009 to assess municipal vulnerability to sea-level change and potential adaptations. This paper describes the methods used by the city to assess its vulnerability. One year after the study, an adaptation strategy was presented to the city council. A public outreach campaign was undertaken during the project that targeted decision makers and local stakeholders. A project team was formed, public forums held, a sea-level rise sub-committee established, and the media involved. Municipal vulnerability was investigated through an inundation model and by mapping critical assets and infrastructure. Results suggest that a tipping point exists when sea-level rise reaches $0.6 \mathrm{~m}$ above the 2011 level. In response to these findings, it is recommended that the city's comprehensive management plan be updated to account for sea-level change projections.

Peloso, M. E. and Caldwell, M. R., 2011. Dynamic property rights: The public trust doctrine and takings in a changing climate. Stanford Environmental Law Journal, 30(1), 151-120.

Keywords: beach nourishment, beaches, coastal armoring, legislation, private property rights

Several court cases have recently been filed along the Gulf of Mexico that highlight the current struggle between coastal property owners and the public trust in determining how to best protect eroding shorelines. The state, as the holder of the public trust, has the right to limit coastal development, but must also use care to avoid the liability of a regulatory takings suit. This paper describes the current legislation protecting both parties. In Florida, the public trust doctrine is codified in Article $\mathrm{X}$, Section 11 of the Florida Constitution. It declares that the state has sovereignty over submerged lands and coastal land up to the mean high water line. The doctrine also recognizes the public right to navigation, bathing, fishing, and reasonable access to the beach. On the opposite side, coastal property owners have the right to unrestricted water access, unobstructed water views, and any land added by accretion or water recession. The friction between the two sides arises when the state takes action to preserve the shoreline through beach nourishment activities or by restricting the construction of coastal armament on private property. Under the Beach and Shore Preservation Act, beach nourishment projects can potentially diminish the rights of coastal property owners by setting new property lines for erosion control. The authors argue for the need of adaptive management techniques to balance the rights of the state with the rights of private property owners in future conflicts that are expected to arise with increasing sea level and storm activity.

Ruppert, T., 2011. Reasonable investment-backed expectations: Should notice of rising seas lead to decreased 
expectations for coastal property owners? Journal of Land Use \& Environmental Law, 26(2), 239-276.

Keywords: land-use planning, legislation, private property rights

The balance between the rights of property owners and the responsibility of state and local governments to promote the health, safety, and welfare of the community is a matter of great importance in Florida in light of coastal hazards and sea-level change. Regulations intended to safeguard coastal communities by restricting the use of private property may require compensation to property owners, thereby stifling attempts to adapt to sea-level change. In part, the current legal standard for invoking a regulatory takings claim is whether the regulation conforms to the property owner's reasonable investment-backed expectations at the time of purchase. Factors in determining reasonable investmentbacked expectations are dynamic, but generally revolve around whether the property owner should have anticipated the regulation in light of the regulatory atmosphere at the time of purchase, and whether the owner knew of the problem that the regulation seeks to redress. Mandatory notice to property purchasers of the risks involved in purchasing coastal property, including regulatory regimes in place and hazards unique to coastal properties may be able to shape the reasonable investment-backed expectations of coastal property owners. The author contends that if the notice is sufficient, mandatory, and enforceable, regulatory takings claims can be diminished.

Titus, J.G.; Hudgens, D.E.; Trescott, D.L.; Craghan, M.; Nuckols, W.H.; Hershner, C.H.; Kassakian, J.M.; Linn, C.J.; Merritt, P.G.; McCue, T.M.; O’Connell, J.F.; Tanski J.; and Wang, J., 2009. State and local governments plan for development of most land vulnerable to rising sea level along the U.S. Atlantic coast. Environmental Research Letters, 4(4), 1-50.

Keywords: coastal armoring, habitat migration, Atlantic coast

According to the authors, the two general responses to sea-level rise are shoreline protection and retreat. Since most property owners and land use planners along the U.S. Atlantic coast have yet to decide how they will respond to sea-level change, this paper uses existing land-use maps, land-use plans, regulations, and policies to develop a baseline scenario of how coastal development will proceed with a "business as usual" model. The specific goal was to estimate the quantity and location of coastal land we can expect to follow the "protection" response by adding coastal armoring to protect against sea-level change. Collecting information from 131 jurisdictions from Massachusetts to Florida, coastal land was placed in one of four categories depending on its likeliness of coastal protection/armoring. These categories were: developed land (most likely), intermediate (likely), undeveloped (unlikely), and conservation (least likely). Along Florida's Atlantic coast, $65 \%$ of land was developed, $10 \%$ intermediately developed, $12 \%$ undeveloped, and $13 \%$ in conservation. The authors further argue that the importance of changing the policies of the Clean Water Act to recognize that shoreline protection does cause a significant "cumulative environmental impact" by preventing the landward migration of aquatic habitats. Using their assumptions for coastal armoring and the existing laws, the authors assert that we can expect $75 \%$ of the Florida Atlantic coast to follow the shoreline protection response to sea-level rise.

\section{Wilkins, J., 2011. Is sea level rise "foreseeable"? Does it matter? Journal of Land Use \& Environmental Law, 26(2), 437-501.}

Keywords: inundation, land-use planning, legislation, private property rights, utilities

Florida's waiver of sovereign immunity in certain circumstances has allowed private citizens to sue the state for flood damage caused by state action. Several cases are discussed in this paper in which the courts judged the state as liable or not liable for the flooding of private property. Factors considered in these decisions included, 1) whether the state owns the facilities that caused the flood to private property (e.g., stormwater drainage systems), 2) whether the flooding has caused a substantial deprivation of beneficial use of the property, 3 ) whether sovereign immunity has been waived or reserved, and 4) whether the flooding was caused by planning decisions or ministerial functions. Florida's Local Government Comprehensive Planning and Land Development Regulation Act contains policies applicable to land-use planning in coastal areas, including how to limit development in high-hazard areas and how to safeguard human life from natural disasters. Nonetheless, development persists in hazardous areas. The author asserts that if sea-level change and other coastal hazards are not taken into account in local land-use planning decisions, it is possible that the decision could be challenged as being inconsistent with the act, giving rise to liability for the foreseeable impacts of sea-level change.

Wyman, J. B., 2010. In states we trust: the importance of the preservation of the public trust doctrine in the wake of climate change. Vermont Law Review, 35, 507-514. 
Keywords: beach nourishment, beaches, legislation, private property rights, Walton County

According to this article, every state and local jurisdiction owes its citizens the responsibility of preserving its coastline as an important natural resource when it is threatened by sea-level change, erosion, and storms of increasing intensity. In Florida, submerged lands up to the mean high water line are held in trust for the public's use and benefit. Florida's Beach and Shore Preservation Act granted the state's environmental agency the ability to protect the public trust by authorizing state-sponsored beach nourishment projects. The act was challenged by several private property owners in Walton County, who argued that beach nourishment deprived them of the common law right to accretion (the extension of private property rights to sediment deposited by the ocean) and the right of contact with the water. Both the Florida and the U.S. Supreme Courts rejected these arguments. The author contends that the victory of the agency in both the Florida and U.S. Supreme Court in Stop the Beach Renourishment, Inc. v. Florida Department of Environmental Protection was a victory for the public, and for all states that wish to meet their responsibility of preserving the nation's shoreline for the public benefit.

\section{Zhang, K. and Leatherman, S., 2011. Barrier island population along the U.S. Atlantic and Gulf coasts. Journal of Coastal Research, 27(2), 356-363.}

Keywords: barrier islands, land-use planning, vulnerability, Atlantic coast, Gulf of Mexico

The vulnerability of human populations living on barrier islands along the Atlantic and Gulf coasts to sea-level change was investigated using geographic and census data. Length and areas of barrier islands were quantified. Population densities were also calculated based on 2000 census data. Results showed that one-third of the barrier islands in the study site occur in Florida and half of the 1.4 million people living on barrier islands are in Florida. Additionally, population densities on barrier islands are much higher than population densities on the mainland in these coastal states. A population increase of $14 \%$ was also seen on these barrier islands between 1990 and 2010. This rate of increase is approximately equal to the population increase seen throughout the coastal states.

\section{Conclusions}

In addition to summarizing the literature, this work also identified keywords relating to sea-level rise for each article. These keywords are not necessarily the same keywords that the individual authors assigned for each paper at the time of publication. Instead, they were assigned for the purposes of this bibliographic summary. An investigation of these keywords was conducted to enable a gap analysis of the literature. As stated in the introduction, there is a vast body of literature prepared by governmental agencies, conservation groups, and universities that is not reviewed in this bibliography, and we do not imply that these topics are not covered in the larger body of literature.

Based on this analysis, the most discussed topics were habitat migration, modeling, inundation, land-use planning, legislation, and private property rights (Table 1). An analysis of "place-based" keywords was conducted to assess the frequency of studies occurring in specific areas within Florida (Table 2). The most discussed locations included the Everglades, the Gulf of Mexico, the Big Bend region, and the Florida Keys. Ecological and physical research generally tended to focus on unpopulated areas or areas of high ecological value, whereas social research focused more on developed areas.

An analysis of the frequency of occurrence of habitat types was also conducted (Table 3 ). This analysis shows that wetlands, beaches, and forests are the most frequently studied habitat types. Though mangroves are a type of wetland habitat they were included as their own keyword because of the high frequency of occurrence. Barrier islands did not receive as much attention as the aforementioned habitat types. Additionally, lacking in the literature were studies on aquatic (non-emergent) habitats such as seagrass beds, estuarine habitats, and hard-bottom habitats, such as coral reefs and oyster reefs.

\section{Physical Sciences}

The current physical science literature is represented by 18 papers containing a combination of historical data (e.g., tide gauges, historic sea-level rise, habitat migration) and predictive sciences (modeling). Modeling, a keyword for seven of the papers, is the most common theme in the physical science literature. This research uses mathematical models (e.g., SLAMM, SLOPE, and GCMs) to predict the probability of local land area inundation or habitat migration under various sea-level rise scenarios (with the scenarios used coming from other research). Other common themes include sea-level rise prediction (six occurrences) and tide gauge, habitat migration, and inundation (five occurrences each).

There appears to be a lack of literature pertaining to nearshore currents and sedimentation patterns in Florida that 
may be affected by sea-level rise. Data such as sediment deposition, beach dynamics, and barrier island movement could represent crucial parameters for predictive modeling as changes in sedimentation patterns could significantly increase or decrease local sea-level rise vulnerability. We did not find any peer-reviewed physical science publications regarding saltwater intrusion or groundwater modeling as it relates to sea-level rise. Finally, while there were numerous papers highlighting tide gauge data from Florida, we did not find Florida-specific references to satellite altimetry to estimate sea level, a form of measurement (generally used for estimating global sea-level rise) that has been available for the past $20+$ years.

\section{Biological Sciences}

The biological science literature reviewed in this bibliography includes 15 papers. The most popular themes presented are habitat migration and salinity (six occurrences), followed by biological indicators, threatened and endangered species, and wildlife habitat (five occurrences). There are several studies that track the movement of organisms (e.g., vegetation, mollusks, and oysters) with known salinity thresholds across coastal areas and use the results as a measure of sea-level rise. Other literature focuses on specific species of interest (especially threatened and endangered species) and uses models to predict the potential loss of habitat due to sea-level rise.

Some topics that were not found in the biological science literature include aquatic non-wetland habitats, especially seagrasses and hard-bottom habitats such as coral reefs. There is also limited coverage of intangible ecosystem services provided by coastal environments, such as nutrient cycling, pollution removal, storm abatement, and shoreline protection.

\section{Social Sciences}

The current social science literature is represented by 22 papers that analyze legal developments, governmental policies, infrastructure vulnerability, and adaptation methods. Private property rights (eight occurrences) is a common theme in the social science literature, especially in reference to conflicts between private property rights and beach preservation activities, such as beach nourishment. Landuse planning (nine occurrences) emphasizes vulnerability assessments and citizen involvement in local planning for sea-level rise. Other topics include legislation, governmental responsibility for relocating vulnerable citizens, governmental liability for failing to plan for sea-level rise, and the state's sovereignty for activities involving beach nourishment and coastal building setbacks.
Social science topics that were not addressed in the literature of this bibliography include estimations of the economic impacts of sea-level rise, public perceptions of sea-level rise, and legal liability for contributing to or exacerbating sea-level rise.

\section{Acknowledgments}

This publication was supported by the National Sea Grant College Program of the U.S. Department of Commerce's National Oceanic and Atmospheric Administration (NOAA), Grant No. NA10-OAR4170079. The views expressed are those of the authors and do not necessarily reflect the views of these organizations. Additional copies are available by contacting Florida Sea Grant, University of Florida, PO Box 110409, Gainesville, FL, 32611-0409, (352) 392.2801, http://www.flseagrant.org. Additional support for this project was made possible by the Florida Climate Institute and the Southeast Climate Consortium.

\section{Literature Cited}

Intergovernmental Panel on Climate Chage. 2007. Climate Change 2007: Synthesis Report; Pachauri, R. K. and Reisinger, A., Eds.; IPCC: Geneva, Switzerland. 
Table 1. Frequency of occurrence of general keywords.

\begin{tabular}{|l|l|l|l|}
\hline General Keyword & Frequency & General Keyword & Frequency \\
\hline beach nourishment & 6 & modeling & 9 \\
\hline biological indicator & 5 & private property rights & 8 \\
\hline citizen involvement & 5 & remote sensing & 3 \\
\hline coastal armoring & 4 & salinity & 7 \\
\hline fisheries & 2 & sea-level rise acceleration & 4 \\
\hline greenhouse gases & 3 & sea-level rise prediction & 6 \\
\hline groundwater & 2 & storms & 7 \\
\hline habitat migration & 12 & threatened and endangered species & 7 \\
\hline historic sea-level rise & 6 & tide gauge & 6 \\
\hline inundation & 8 & utilities & 5 \\
\hline karst & 1 & vulnerability & 6 \\
\hline land-use planning & 9 & water quality & 2 \\
\hline legislation & 8 & wildlife habitat & 5 \\
\hline
\end{tabular}

Table 2. Frequency of occurrence of places within the keywords.

\begin{tabular}{|l|l|l|l|}
\hline Place Keyword & Frequency & Place Keyword & Frequency \\
\hline Apalachicola & 1 & Mayport & 2 \\
\hline Atlantic coast & 3 & Miami-Dade County & 2 \\
\hline Big Bend & 5 & Palm Beach County & 1 \\
\hline Biscayne Bay & 1 & Panhandle & 1 \\
\hline Broward County & 2 & Pensacola & 1 \\
\hline Everglades & 8 & Sarasota & 3 \\
\hline Florida Keys & 4 & Satellite Beach & 1 \\
\hline Gulf of Mexico & 8 & Ten Thousand Islands & 1 \\
\hline Indian River & 1 & Walton County & 1 \\
\hline Key West & 1 & & \\
\hline
\end{tabular}

Table 3. Frequency of occurrence of habitat types within the keywords.

\begin{tabular}{|l|l|}
\hline Habitat Type Keyword & Frequency \\
\hline barrier islands & 2 \\
\hline beaches & 7 \\
\hline forests & 6 \\
\hline mangroves & 5 \\
\hline wetlands & 9 \\
\hline
\end{tabular}

